\title{
RELASI HUKUM DAN POLITIK DALAM SISTEM HUKUM INDONESIA
}

\author{
(Legal and Political Relations in Law System of Indonesia) \\ Merdi Hajiji \\ Lembaga Pemberdayaan Masyarakat Kota Bandung \\ Jalan Guntursari No 12 Bandung \\ Email: hajimerdi@yahoo.co.id
}

Naskah diterima: 20 November 2013; revisi: 22 November 2013; disetujui: 17 Desember 2013

\begin{abstract}
Abstrak
Berbicara tentang relasi antara hukum dan politik adalah bagaimana hukum bekerja dalam sebuah situasi politik tertentu dan tentang hukum sebagai perwujudan dari keadilan. Tulisan ini membahas bagaimana relasi dua hal tersebut di Indonesia serta faktor-faktor apa saja yang mempengaruhi lahirnya hukum dari aktivitas politik dengan menitikberatkan dalam konteks hubungan antara politik dan hukum, termasuk di dalamnya mengkaji apa pengaruhnya politik terhadap hukum dalam sistem hukum di Indonesia. Dengan menggunakan metode penelitian deskriptif analisis melalui studi kepustakaan, didapatkan kesimpulan bahwa hukum di Indonesia sangat dipengaruhi oleh aliran positivisme yang memandang hukum itu terbatas pada yang tertuang dalam peraturan perundang-undangan, bahkan aliran ini akan terus mengokohkan dirinya dalam perkembangan sistem hukum Indonesia ke depan. Nilai-nilai moral dan etika serta kepentingan rakyat dalam kenyataan-kenyataan sosial di masyarakat hanya sebagai pendorong untuk terbentuknya hukum yang baru melalui perubahan, koreksi serta pembentukan peraturan perundang-undangan yang baru.
\end{abstract}

Kata Kunci: hukum, politik, perundang-undangan

\begin{abstract}
Discussing about the relationship between law and politics is how the law works in a particular political situation and about the law as the embodiment of justice. This article discuss relationship of law and politics in Indonesia and the factors that influence the laws of political activity with emphasis in the context of the relationship between politics and law, including assessing what political influence against the law in the legal system in Indonesia. By using descriptive analysis through the study of literature, it was concluded that the law in Indonesia is influenced by the flow of legal positivism that sees it is limited to that contained in the legislation, it will continue to flow even establish itself in the development of the Indonesian legal system forward. Moral values and ethics and people's interest in social realities in society just as the driving force for the formation of the new law through changes, corrections and drafting new legislation.
\end{abstract}

Keywords: law, politic, legislation 


\section{A. Pendahuluan}

Berbicara tentang relasi antara hukum dan politik adalah berbicara bagaimana hukum bekerja dalam sebuah situasi politik tertentu. Dalam hal ini yang dimaksud adalah hukum sebagai perwujudan dari nilai-nilai yang berkembang dan nilai-nilai yang dimaksud adalah keadilan. Dengan demikian idealnya hukum dibuat dengan mempertimbangkan adanya kepentingan untuk mewujudkan nilai-nilai keadilan tersebut. Dengan ciri-ciri mengandung perintah dan larangan, menuntut kepatuhan dan adanya sanksi, maka hukum yang berjalan akan menciptakan ketertiban dan keadilan di masyarakat.

Hubungan antara hukum dan politik manakah yang seyogianya lebih dominan, kekuasaan hukum atau kekuasaan politik? Jawaban atas pertanyaan ini, tergantung pada persepsi kita sendiri tentang apa yang kita maksudkan sebagai hukum, dan apa yang kita maksudkan dengan politik. Jika kita berpandangan nondogmatik, dan memandang hukum bukan sekedar peraturan yang dibuat oleh kekuasaan politik, maka tentu saja persoalan lebih lanjut tentang hubungan kekuasaan hukum dan kekuasaan politik masih bisa berkepanjangan. Namun jika kita menganut pandangan "positif" yang memandang hukum semata-mata hanya produk kekuasaan politik, maka rasa tak relevan lagi pertanyaan tentang hubungan antara kekuasaan hukum dan kekuasaan politik, karena pada akhirnya mereka mengidentikkan antara hukum dan politik tersebut.
Law is a command of the Lawgiver (hukum adalah perintah dari penguasa), dalam arti perintah dari mereka yang memiliki kekuasaan tertinggi atau yang memegang kedaulatan. Demikian John Austin, seperti dikutip oleh Prof Lili Rasyidi. Perdebatan mengenai hububngan hukum dan politik memiliki akar sejarah panjang dalam ilmu hukum. Bagi kalangan penganut aliran positivisme hukum seperti John Austin, hukum adalah tidak lain dari produk politik atau kekuasaan. Pada sisi lain, pandangan berbeda datang dari kalangan aliran sejarah dalam ilmu hukum, yang melihat hukum tidak dari dogmatika hukum dan undang-undang semata, akan tetapi dari kenyataan-kenyataan sosial yang ada dalam masyarakat dan berpandangan bahwa hukum itu tergantung pada penerimaan umum dalam masyarakat dan setiap kelompok menciptakan hukum yang hidup. ${ }^{1}$

Keadilan akan dapat terwujud apabila aktifitas politik yang melahirkan produk-produk hukum memang berpihak pada nilai-nilai keadilan itu sendiri. Terlepas bahwa dalam proses kerjanya lembaga-lembaga hukum harus bekerja secara independen untuk dapat memberikan kepastian dan perlindungan hukum, dasar dari pembentukan hukum itu sendiri yang dilakukan oleh lembaga-lembaga politik juga harus mengandung prinsipprinsip membangun supremasi hukum yang berkeadilan. $^{2}$

Dalam konteks Indonesia, cita dan fakta yang berkaitan dengan penegakan keadilan masih belum dapat bertemu. Harapan akan adanya instrumen dan pengadilan yang fair 
dan berkadilan sangat bertentangan dengan maraknya mafia-mafia peradilan dan praktekpraktek hukum yang menyimpang. Pada tingkatan tertentu Indonesia bahkan dapat dikatakan berada pada situasi lawlessness, misalnya, sekelompok orang bersenjata dapat bergerak bebas dan melakukan tindak kekerasan tanpa mendapat tindakan apa pun dari aparat kepolisian, massa dapat mengadili pencuri kelas teri dan membakarnya, sementara pengadilan membebaskan koruptor kelas kakap. Dunia hukum Indonesia berada dalam kuasa "demoralisasi, disorientasi, dehumanisasi dan dekadensi". 3

Pandangan Mac Iver yang membedakan dua jenis hukum. Pertama, hukum yang berada di bawah pengaruh politik; dan Kedua hukum yang berada di atas politik. Yang berada di atas politik, hanya konstitusi, sedang sisanya semua berada di bawah politik. Inilah pandangan yang realistis tentang hubungan hukum dan politik. Salah satu contoh yang membuktikan kebenaran pandangan Mac Iver ini adalah bahwa lahirnya undang-undang jelas karya para politisi.

Bahwa tidak dapat disangkal terdapat hubungan yang sangat erat antara hukum dan politik, antara asas-asas hukum dan pranatapranata hukum, serta antara ideologi-ideologi politik dan lembaga-lembaga pemerintah. Sangat sering mendengar pernyataan para yuris dengan slogan mereka bahwa: Hukum berdiri diatas dan melewati politik. Yang mereka maksudkan adalah keinginan mereka untuk mewujudkan suatu masyarakat di mana para hakim tidak dikekang oleh pengaruh dogma politik.

\section{B. Permasalahan}

1. Bagaimana relasi antara hukum dan politik di Indonesia?

2. Faktor-faktor apa saja yang mempengaruhi bahwa hukum dilahirkan dari aktivitas politik?

\section{Metode Penelitian}

Metode penelitian yang digunakan dalam penulisan ini adalah metode penelitian deskriftif analitis, metode deskriftif analitis pada dasarnya meneliti kaidah-kaidah dari sumber data, menelaah permasalahan dengan berpedoman pada data sekunder yaitu: bahan hukum primer, sekunder dan tersier. Bahan hukum primer yang dimaksud adalah Undang-Undang Dasar 1945, undang-undang, peraturan pemerintah, dan peraturan perundang-undangan lain yang berkaitan dengan judul penelitian. ${ }^{4}$

Bahan hukum sekunder yang dimaksud adalah doktrin, ajaran para ahli, hasil karya ilmiah para ahli, berita-berita dan hasil wawancara pihak terkait yang diperoleh dari surat kabar serta situs-situs internet yang relevan dengan judul penelitian.

Data di atas dikumpulkan melalui studi kepustakaan (library research), penelurusan melalui media internet (online research), dalam hal ini penulis menitikberatkan dalam konteks hubungan antara politik dan hukum, termasuk di dalamnya mengkaji apa pengaruhnya politik terhadap hukum dalam sistem hukum di Indonesia, lalu apakah peranan politikus dalam melahirkan produk-produk hukum. Kemudian penulis akan mencoba menggambarkan tentang

\footnotetext{
Makalah Relasi Politik dan Hukum di Indonesia Mouvty Makaarim al-Akhlaq.

4 Soekanto, Soerjono dan Sri Mamudji, Penelitian Hukum Normatif: Suatu Tinjauan Singkat (Jakarta: Raja Grafindo Persada, 2001).
} 
relasi hukum dan politik dalam sistem Hukum Indonesia.

\section{Pembahasan}

\section{Hukum dalam Subordinasi Politik}

Runtuhnya Orde Baru dan keinginan untuk membangun kembali suatu tatanan masyarakat yang demokratis yang memunculkan upayaupaya peninjauan ulang, revisi dan amandemen terhadap segala bentuk sistem dan perangkat hukum yang ada. Namun sejarah mencatat bahwa proses lahirnya hukum memang tidak lepas dari sejarah kekuasaan atau politik itu sendiri. Sejak masa Imperium Roma sampai dengan Hitler, Sejak masa Sriwijaya hingga Megawati Sokarnoputri.

Dalam sejarah Indonesia, Orde Baru sebenarnya sekadar menyempurnakan apa yang dikenal dengan "The Ducth Law of The Sea", suatu upaya kolonial Belanda untuk mengintervensi hukum adat yang berlaku di nusantara. Prinsipnya hukum tersebut dugunakan sebagai instrumen kepentingan penjajah di wilayah jajahannya dimana VOC misalnya mendiskriminasikan pribumi sebagai warga kelas dua.

Ada lima langkah yang dilakukan Orde Baru untuk "menyempurnakan" hukum sebagai alat untuk menjinakkan masyarakat: Pertama, melakukan kooptasi terhadap lembaga-lembaga tinggi negara, termasuk Mahkamah Agung (MA) sehingga menyebabkan MA kehilangan fungsi pro justitia-nya. Kedua, memusnahkan pranata sosial, misalnya peradilan adat atau kearifan lokal yang selama bertahun-tahun menjadi mekanisme penjaga keseimbangan dalam lingkungan adat tertentu. Ketiga, kanalisasi semua pertarungan dan konflik yang terjadi di masyarakat pada peradilan yang disediakan negara sehingga negara dapat mengontrol konteks, peristiwa dan putusan yang akan ditetapkan. Keempat, membentuk instrumeninstrumen quasi untuk menyelesaikan masalah masyarakat. Pengadilan, DPR dan lembaga tinggi negara lainnya dibentuk seakan-akan bekerja untuk keadilan, namun ternyata hanya purapura, tidak beres dan tidak jelas. Dan kelima, persoalannya bukan hanya imparsialitas dan independensi, namun juga masuknya praktekpraktek kolusi, korupsi dan nepotisme. ${ }^{5}$

Dengan kata lain, hukum yang berada dalam kuasa negara menjadi semakin tak berdaya ketika praktek-praktek politisasi lebih dominan ketimbang praktek hukum yang sebenarnya. Law enforcement menjadi kehilangan ruang, sehingga Ronald Katz kemudian menyebutkan bahwa apa yang terjadi di Indonesia adalah law without law, ada hukum tapi tidak berguna.

\section{Pandangan Aliran Positivis Tentang Hukum}

Aliran positivisme hukum berasal dari ajaran sosiologis yang dikembangkan oleh filosof Perancis; August Comte (1798-1857), yang berpendapat bahwa terdapat kepastian adanya hukum-hukum perkembangan mengatur roh manusia dan segala gejala hidup bersama dan itulah secara mutlak. August Comte hanya mengakui hukum yang dibuat oleh negara. ${ }^{6}$ Untuk memahami positivisme hukum tidak 
dapat diabaikan metodologi positivis dalam sains yang mengharuskan dilakukannya validasi dengan metode yang terbuka atas setiap kalin atau proposisi yang diajukan. Karena itu bukti empirik adalah syarat universal untuk diterimanya kebenaran dan tidak berdasarkan otoritas tradisi atau suatu kitab suci. Positivisme hukum mempunyai pandangan yang sama tentang diterimanya validasi. Seperti halnya positivisme sains yang tidak dapat menerima pemikiran dari suatu proposisi yang tidak dapat diverifikasi atau yang tidak dapat difalsifikasi, tetapi karena hukum itu ada karena termuat dalam perundang-undangan apakah dipercaya atau tidak. Hukum harus dicantumkan dalam undang-undang oleh lembaga legislatif dengan memberlakukan, memperbaiki dan merubahnya.

Positivisme hukum berpandangan bahwa hukum itu harus dapat dilihat dalam ketentuan undang-undang, karena hanya dengan itulah ketentuan hukum itu dapat diverifikasi. Adapan yang di luar undang-undang tidak dapat dimasukkan sebagai hukum karena hal itu berada di luar hukum. Hukum harus dipisahkan dengan moral, walaupun kalangan positivis mengakui bahwa focus mengenai norma hukum sangat berkaitan dengan disiplin moral, teologi, sosiologi dan politik yang mempengaruhi perkembangan sistem hukum. Moral hanya dapat diterima dalam sistem hukum apabila diakui dan disahkan oleh otoritas yang berkuasa dengan memberlakukannya sebagai hukum. ${ }^{7}$

Lebih jauh, pandangan dan pendapat dari mazhab positivisme ini dapat ditelusuri dari pendapat dan pandangan dari para penganut terpenting dari mazhab ini antara lain John Austin, seorang ahli hukum yang berkebangsaan Inggeris yang mewakili pandangan positivis dari kelompok penganut sistem hukum Common Law dan Hans Kelsen, seorang ahli hukum yang berkebangsaan Jerman yang mewakili pandangan positivis dari kelompok penganut sistem hukum Eropa Kontinental.

Menurut John Austin, hukum adalah perintah kaum yang berdaulat. IImu hukum berkaitan dengan hukum positif atau dengan ketentuan-ketentuan lain yang secara tegas disebut demikian. ${ }^{8}$ Pendapat Austin sangat dipengaruhi oleh pandangannya mengenai kedaulatan negara yang memiliki dua sisi yaitu sisi eksternal dalam bentuk hukum internasional dan sisi internal dalam bentuk hukum positif. Kedaulatan negara menuntut ketaatan dari penduduk warga negara. Lebih lanjut menurut Austin, ketaatan ini berbeda dengan ketaatan seseorang karena ancaman senjata. Ketaatan warga negara terhadap kedaulatan negara didasarkan pada legitimasi. Menurut pandangan Austin, hukum sebagai suatu sistem yang logis, tetap dan bersifat tertutup (closed logical system). ${ }^{9}$ Hukum dipisahkan secara tegas dari keadilan dan tidak didasarkan pada nilai-nilai yang baik atau buruk. Ada empat unsur hukum yaitu adanya perintah, sanksi, kewajiban dan kedaulatan. Ketentuan yang tidak memenuhi ke empat unsur ini tidak dapat dikatakan sebagai positive law.

Hamdan Zoelva, "Hukum dan Politik Dalam Sistem Hukum Indonesia", Official Blog Hamdan Zoelva, http:// hamdanzoelva.wordpress.com/ (diakses 18 Oktober 2013).

8 Achmad Ali, Op.Cit., hlm. 267.

$9 \quad$ Lili Rasyidi \& Ira Rasyidi, Op.Cit., hlm.59 
Selanjutnya Lili Rasyidi menyimpulkan pokok-pokok ajaran Analytical Jurisprudence dari Austin, yaitu: ${ }^{10}$

a. Ajarannya tidak berkaitan dengan soal atau penilain baik dan buruk, sebab penilaian tersebut berada di luar hukum;

b. Walau diakui adanya hukum moral yang berpengaruh terhadap masyarakat, namun secara yuridis tidak penting bagi hukum.

c. Pandangannya bertolak belakang dengan baik penganut hukum alam maupun mazhab sejarah;

d. Hakekat dari hukum adalah perintah. Semua hukum positif adalah perintah dari yang berdaulat/penguasa.

e. Kedaulatan adalah hal di luar hukum, yaitu berada pada dunia politik atau sosiologi karenanya tidak perlu dipersoalkan sebab dianggap sebagai sesuatu yang telah ada dalam kenyataan;

f. Ajaran Austin kurang/tidak memberikan tempat bagi hukum yang hidup dalam masyarakat.

Dari kalangan penganut sistem hukum Eropa Kontinental, Hans Kelsen yang dikenal dengan ajaran hukum murninya selalu digolongkan sebagai penganut aliran positivisme ini. Ada dua teori yang dikemukakan oleh Hans Kelsen yang perlu diketengahkan. Pertama, ajarannya tentang hukum yang bersifat murni dan kedua, berasal dari muridnya Adolf Merkl, yaitu stufenbau des recht yang mengutamakan tentang adanya hierarkis daripada perundangundangan. Intiajaran hukum murni Hans Kelsen adalah bahwa hukum itu harus dipisahkan dari anasir-anasir yang tidak yuridis seperti etis, sosiologis, politis dan sebagainya. Dengan demikian Kelsen tidak memberikan tempat bagi betrlakunya hukum alam. Hukum merupakan sollen yuridis semata-mata yang terlepas dari das sein / kenyataan sosial. ${ }^{11}$

Sedangkan ajaran stufentheorie berpendapat bahwa suatu sistem hukum adalah suatu hierarkis dari hukum dimana suatu ketentuan hukum tertentu bersumber pada ketentuan hukum lainnya yang lebih tinggi. Sebagai ketentuan yang paling tinggi adalah Grundnorm atau norma dasar yang bersifat hipotetis. Ketentuan yang lebih rendah adalah lebih konkrit daripada ketentuan yang lebih tinggi. Ajaran murni tentang hukum adalah suatu teori tentang hukum yang senyatanya dan tidak mempersoalkan hukum yang senyatanya itu, yaitu apakah hukum yang senyatanya itu adil atau tidak adil. ${ }^{12}$

Selanjutnya H.L.A. Hart (seperti dikutip oleh Lili Rasyidi, menguraikan tentang ciriciri positivisme pada ilmu hukum dewasa ini sebagai berikut: ${ }^{13}$

a. Pengertian bahwa hukum adalah perintah dari manusia (command of human being);

b. Pengertian bahwa tidak ada hubungan mutlak/penting antara hukum (law) dan moral atau hukum sebagaimana yang berlaku/ada dan hukum yang sebenarnya;

c. Pengertian bahwa analisis konsepsi hukum adalah : 
1) Mempunyai Arti Penting,

2) Harus Dibedakan Dari Penyelidikan :

- Historis Mengenai Sebab-Musabab Dan Sumber-Sumber Hukum,

- Sosiologis Mengenai Hubungan Hukum Dengan Gejala Sosial Lainnya, Dan

- Penyelidikan Hukum Secara Kritis Atau Penilain, Baik Yang Berdasarkan Moral, Tujuan Sosial, Fungsi Hukum Dan LainLainnya.

d. Pengertian bahwa sistem hukum adalah sistem yang logis, tetap dan bersifat tertutup dalam mana keputusan-keputusan hukum yang benar/tepat biasanya dapat diperoleh dengan alat-alat logika dari peraturanperaturan hukum yang telah ditentukan sebelumnya tanpa memperhatikan tujuantujuan sosial, politik dan ukuran-ukuran moral;

e. Pengertian bahwa pertimbanganpertimbangan moral tidak dapat dibuat atau dipertahankan sebagai pernyataan kenyataan yang harus dibuktikan dengan argumentasi-argumentasi

pembuktian atau percobaan.

Dengan demikian kita dapat pula mengatakan, karena negara adalah ekspresi atau merupakan forum kekuatan-kekuatan politik yang ada di dalam masyarakat, maka hukum adalah hasil sebagian pembentukan keputusan yang diambil dengan cara yang tidak langsung oleh penguasa. Penguasa mempunyai tugas untuk mengatur dengan cara-cara umum untuk mengatasi problema-problema kemasyarakatan yang serba luas dan rumit, pengaturan ini merupakan obyek proses pengambilan keputusan politik, yang dituangkan kedalam aturan-aturan, yang secara formal diundangkan. Jadi dengan demikian hukum adalah hasil resmi pembentukan keputusan politik. ${ }^{14}$

\section{Pengaruh Politik Dalam Pembentukan Hukum di Indonesia}

Menurut Daniel S. Lev, yang paling menentukan dalam proses hukum adalah konsepsi dan struktur kekuasaan politik, yaitu bahwa hukum sedikit banyak selalu merupakan alat politik, dan bahwa tempat hukum dalam negara, tergangtung pada keseimbangan politik, defenisi kekuasaan, evolusi idiologi politik, ekonomi, sosial, dan seterusnya. ${ }^{15}$

Walaupun kemudian proses hukum yang dimaksud tersebut di atas tidak diidentikan dengan maksud pembentukan hukum, namun dalam prateknya seringkali proses dan dinamika pembentukan hukum mengalami hal yang sama, yakni konsepsi dan struktur kekuasaan politiklah yang berlaku di tengah masyarakat yang sangat menentukan terbentuknya suatu produk hukum. Maka untuk memahami hubungan antara politik dan hukum di negara mana pun, perlu dipelajari latar belakang kebudayaan, ekonomi, kekuatan politik di dalam masyarakat, keadaan lembaga negara, dan struktur sosialnya, selain institusi hukumnya sendiri.

Pengertian hukum yang memadai seharusnya tidak hanya memandang hukum itu sebagai suatu perangkat kaidah dan azasazas yang mengatur kehidupan manusia dalam masyarakat, tetapi harus pula mencakup

14 Ibid., hlm. 93.

15 Daniel S. Lev, Hukum Dan Politik di Indonesia, Kesinambungan dan Perubahan, Cet I (Jakarta: LP3S, 1990), hlm. Xi.i 
lembaga (institutions) dan proses (process) yang diperlukan untuk mewujudkan hukum dalam kenyataan. ${ }^{16}$

Dari kenyataan ini disadari, adanya suatu ruang yang absah bagi masuknya suatu proses politik melalui wadah institusi politik untuk terbentuknya suatu produk hukum. Sehubungan dengan itu, ada dua kata kunci yang akan diteliti lebih jauh tentang pengaruh kekuasaan dalam hukum yakni mencakup kata "process" dan kata "institutions," dalam mewujudkan suatu peraturan perundang-undangan sebagai produk politik. Pengaruh itu akan semakin nampak pada produk peraturan perundang-undang oleh suatu institusi politik yang sangat dipengaruhi oleh kekuatan-kekuatan politik yang besar dalam institusi politik. Sehubungan dengan masalah ini, Miriam Budiarjo berpendapat bahwa kekuasaan politik diartikan sebagai kemampuan untuk mempengaruhi kebijaksanaan umum (pemerintah) baik terbentuknya maupun akibat-akibatnya, sesuai dengan pemegang kekuasaan. ${ }^{17}$ Dalam proses pembentukan peraturan hukum oleh institusi politik peranan kekuatan politik yang duduk dalam institusi politik itu adalah sangat menentukan. Institusi politik secara resmi diberikan otoritas untuk membentuk hukum hanyalah sebuah institusi yang vacum tanpa diisi oleh mereka diberikan kewenangan untuk itu. Karena itu institusi politik hanya alat belaka dari kelompok pemegang kekuasaan politik. Kekuatan-kekuatan politik dapat dilihat dari dua sisi yakni sisi kekuasaan yang dimiliki oleh kekuatan politik formal (institusi politik) dalam hal ini yang tercermin dalam struktur kekuasaan lembaga negara, seperti Presiden, Dewan Perwakilan Rakyat dan lembaga-lembaga negara lainnya dan sisi kekuatan politik dari infrastruktur politik adalah seperti: partai politik, tokoh-tokoh masyarakat, organisasi kemasyarakatan, Lembaga Swadaya Masyarakat, organisasi profesi dan lain-lain. Dengan demikian dapatlah disimpulkan bahwa pembentukan produk hukum adalah lahir dari pengaruh kekuatan politik melalui proses politik dalam institusi negara yang diberikan otoritas untuk itu.

Seperti telah diuraikan dalam bagian terdahulu bahwa teori-teori hukum yang berpengaruh kuat terhadap konsep-konsep dan implementasi kehidupan hukum di Indonesia adalah teori hukum positivisme. Pengaruh teori ini dapat dilihat dari dominannya konsep kodifikasi hukum dalam berbagai jenis hukum yang berlaku di Indonesia bahkan telah merambat ke sistem hukum internasional dan tradisional. ${ }^{18}$ Demikian pula dalam praktek hukum pun di tengah masyarakat, pengaruh aliran poisitvis adalah sangat dominan. Apa yang disebut hukum selalu dikaitkan dengan peraturan perundang-undangan, di luar itu, dianggap bukan hukum dan tidak dapat dipergunakan sebagai dasar hukum. Nilai-nilai dan norma di luar undang-undang hanya dapat diakui apabila dimungkinkan oleh undangundang dan hanya untuk mengisi kekosongan peraturan perundang-undang yang tidak atau belum mengatur masalah tersebut. 
Pengaruh kekuatan-kekuatan politik dalam membentuk hukum dibatasi ruang geraknya dengan berlakunya sistem konstitusional berdasarkan checks and balances, seperti yang dianut Undang-Undang dasar 1945 (UUD 1945) setelah perubahan. Jika diteliti lebih dalam materi perubahan UUD 1945 mengenai penyelenggaraan kekuasaan negara adalah mempertegas kekuasaan dan wewenang masing-masing lembaga-lembaga negara, mempertegas batas-batas kekuasaan setiap lembaga negara dan menempatkannya berdasarkan fungsi-fungsi penyelenggaraan negara bagi setiap lembaga negara. Sistem yang demikian disebut sistem "checks and balances", yaitu pembatasan kekuasaan setiap lembaga negara oleh undang-undang dasar, tidak ada yang tertinggi dan tidak ada yang rendah, semuanya sama di atur berdasarkan fungsifungsi masing-masing.

Dengan sistem yang demikian, memberikan kesempatan kepada setiap warga negara yang merasa dirugikan hak konstitusionalnya oleh produk politik dari institusi politik pembentuk hukum untuk mengajukan gugatan terhadap institusi negara tersebut. Dalam hal pelanggaran tersebut dilakukan melalui pembentukan undang-undang maka dapat diajukan keberatan kepada Mahkmah Konstitusi dan dalam hal segala produk hukum dari institusi politik lainnya dibawah undang-undang diajukan kepada Mahkamah Agung.

Di luar kekuatan-kekuatan politik yang duduk dalam institusi-instusi politik, terdapat kekuatan-kekuatan lainnya yang memberikan kontribusi dan mempengaruhi produk hukum yang dilahirkan oleh institusiinstitusi politik. Kekuatan tersebut berbagai kelompok kepentingan yang dijamin dan diakui keberadaan dan perannya menurut ketentuan hukum sebagai negara yang menganut sistem demokrasi, seperti kalangan pengusaha, tokoh ilmuan, kelompok organisasi kemasyarakatan, organisasi profesi, tokoh agama, lembaga swadaya masyarakat dan lain-lain. Bahkan Undang-Undang tentang Pembentukan Peraturan Perundang-undangan dan UndangUndang tentang Pemerintahan Daerah menyatakan "Masyarakat berhak memberikan masukan secara lisan atau tertulis dalam rangka penyiapan atau pembahasan Rancangan Undang Undang dan Rancangan Peraturan Daerah."

Kenyataan di atas menunjukan bahwa pengaruh masyarakat dalam mempengaruhi pembentukan hukum, mendapat tempat dan apresiasi yang begitu luas. Apalagi sejak tuntutan masyarakat dalam mendesakkan reformasi disegala bidang berhasil dimenangkan. Era reformasi telah membawa perubahan besar di segala bidang ditandai dengan lahirnya sejumlah undang-undang yang memberi apresiasi yang begitu besar dan luas. Dalam kasus ini, mengingatkan kita kepada apa yang diutarakan oleh pakar filsafat publik Walter Lippmann, bahwa opini massa telah memperlihatkan diri sebagai seorang master pembuat keputusan yang berbahaya ketika apa yang dipertaruhkan adalah soal hidup mati.

Kenyataan yang perlu disadari, bahwa intensnya pengaruh tuntutan masyarakat terhadap pembentukan hukum dan lahirnya keputusan-keputusan hukum dapat terjadi jika tuntutan rasa keadilan dan ketertiban masyarakat tidak terpenuhi atau terganggu. Rasa ketidakadilan dan terganggunya ketertiban umum akan memicu efek opini yang bergulir seperti bola salju yang semakin besar dan membahayakan jika tidak mendapat salurannya melalui suatu kebijakan produk hukum atau 
keputusan yang memadai untuk memenuhi tuntutan masyarakat tersebut.

Satu catatan penting yang perlu dikemukakan disini untuk menjadi perhatian para lawmaker adalah apa yang menjadi keprihatinan Walter Lippmann, yaitu: "Jika opini umum sampai mendominasi pemerintah, maka disanalah terdapat suatu penyelewengan yang mematikan, penyelewengan ini menimbulkan kelemahan, yang hampir menyerupai kelumpuhan, dan bukan kemampuan untuk memerintah. ${ }^{19}$ Karena itu perlu menjadi catatan bagi para pembentuk hukum adalah penting memperhatikan suara dari kelompok masyarakat yang mayoritas yang tidak punya akses untuk mempengaruhi opini publik, tidak punya akses untuk mempengaruhi kebijakan politik. Disinilah peranan para wakil rakyat yang terpilih melalui mekanisme demokrasi yang ada dalam struktur maupun infrastruktur politik untuk menjaga kepentingan mayoritas rakyat, dan memahami betul norma-norma, kaidahkaidah, kepentingan dan kebutuhan rakyat agar nilai-nilai itu menjadi hukum positif.

\section{Hukum yang Lumpuh dan Dilumpuh- kan?}

Dalam pandangan Lord Acton, upaya perbaikan hukum secara menyeluruh menyangkut perubahan pada the content of the law, the structure of the law, dan the culture of the law. Persoalannya, di Indonesia perubahan yang dilakukan semata-mata baru pada the content of the law, seperti dengan membuat sebanyak mungkin undang-undang dan peraturan untuk mengatasi persoalan di masyarakat, itu pun seringkali tidak didasarkan pada pembacaan yang sungguh-sungguh atas kebutuhan masyarakat akan undangundang dan peraturan serta tidak dirumuskan secara partisipatoris (kasus upaya pemaksaan pengesahan undang-undang Penanggulangan Keadaan Bahaya misalnya). The structure of the law-nya masih dihuni oleh pejabat-pejabat yang bermasalah dan berperan aktif dalam rangkaian keputusan atau praktek hukum yang menyimpang. Apalagi the culture of the lawnya, budaya sogok dan suap jauh lebih menonjol ketimbang profesionalisme sebagai aparatur penegak hukum.

Kondisi hukum yang lumpuh ini semakin diperparah dengan ketiadaan keseriusan pemerintah untuk mengedepankan agenda law erforcement dan hambatan-hambatan politis lainnya. Desakan untuk melakukan pembersihan secara radikal terhadap institusi hukum (Kejaksaan Agung, Kepolisian, Mahkamah Agung) serta pencabutan keputusan-keputusan yang melanggar prinsip-prinsip keadilan (TAP MPRS No XXV dan UU Subversif) yang pernah dirintis Abdurahman Wahid, tidak lagi berlanjut seiring dengan jatuhnya Wahid. Upaya Gus Dur justru dihambat dengan berbagai cara, termasuk dengan penggulingan dirinya, artinya, dalam kondisi dimana proses pemulihan hukum dari kelumpuhan tengah berlangsung, upayaupaya untuk mempertahankan kelumpuhannya juga gencar dilakukan berbagai pihak. Dalam konteks transisional, semua upaya tersebut dilakukan tidak lain untuk mempertahankan ketidakpastian hukum demi membebaskan pihak-pihak yang bermasalah sekaligus tetap mempertahankan previledge yang hanya dapat

$19 \quad$ Ibid., hlm.15 
dipetik dalam situasi ketidakpastian (pengadilan mantan presiden Soeharto misalnya).

\section{Sistem Politik Indonesia}

Untuk memahami lebih jauh tentang mekanisme pembentukan hukum di Indonesia, perlu dipahami sistem politik yang dianut. Sistem politik mencerminkan bagaimana kekuasaan negara dijalankan oleh lembagalembaga negara dan bagaimana meknaisme pengisian jabatan dalam lembaga-lembaga negara itu dilakukan. Inilah dua hal penting dalam mengenai sistem politik yang terkait dengan pembentukan hukum.

Beberapa prinsip penting dalam sistem politik Indonesia yang terkait dengan uraian ini adalah sistem yang berdasarkan prinsip negara hukum, prinsip konstitusional serta prinsip demokrasi. Ketiga prinsip ini saling terkait dan saling mendukung, kehilangan salah satu prinsip saja akan mengakibatkan pincangnya sistem politik ideal yang dianut. Prinsip negara hukum mengandung tiga unsur utama, yaitu pemisahan kekuasaan - check and balances prinsip due process of law, jaminan kekuasaan kehakiman yang merdeka dan jaminan serta perlindungan terhadap hak-hak asasi manusia. Prinsip konstitusional mengharuskan setiap lembaga-lembaga negara pelaksana kekuasaan negara bergerak hanya dalam koridor yang diatur konstitusi dan berdasarkan amanat yang diberikan konstitusi. ${ }^{20}$

Dengan prinsip demokrasi partisipasi publik/ rakyat berjalan dengan baik dalam segala bidang, baik pada proses pengisian jabatanjabatan dalam struktur politik, maupun dalam proses penentuan kebijakan-kebijakan yang diambil oleh berbagai struktur politik itu. Karena itu demokrasi juga membutuhkan transparansi (keterbukaan informasi), jaminan kebebasan dan hak-hak sipil, saling menghormati dan menghargai serta ketaatan atas aturan dan mekanisme yang disepakati bersama.

Dengan sistem politik yang demikianlah berbagai produk politik yang berupa kebijakan politik dan peraturan perundang-undangan dilahirkan. Dalam kerangka paradigmatik yang demikianlah produk politik sebagai sumber hukum sekaligus sebagai sumber kekuatan mengikatnya hukum diharapkan - sebagaimana yang dianut aliran positivis - mengakomodir segala kepentingan dari berbagai lapirsan masyarakat, nilai-nilai moral dan etik yang diterima umum oleh masyarakat. Sehingga apa yang dimaksud dengan hukum adalah apa yang ada dalam perundang-undangan yang telah disahkan oleh institusi negara yang memiliki otoritas untuk itu. Nilai-nilai moral dan etik dianggap telah termuat dalam perundang-undangan itu karena telah melalui proses partisipasi rakyat dan pemahaman atas suara rakyat. Dalam hal produk itu dianggap melanggar norma-norma dan nilai-nilai yang mendasar yang dihirmati oleh masyarakat dan merugikan hak-hak rakyat yang dijamin konstitusi, maka rakyat dapat menggugat negara (institusi) tersebut untuk mebatalkan peraturan yang telah dikeluarkannya dan dinyatakan tidak berlaku. Dengan demikian nilai moral dan etik, kepentingan-kentingan rakyat yang ada dalam kenyataan-kenyataan sosial tetap menjadi hukum yang dicita-citakan yang akan selalui mengontrol dan melahirkan hukum positif yang baru melalui proses perubahan, koreksi dan

20 Jimly Asshidiqie, Pokok-Pokok Hukum Tata Negara Indonesia (Jakarta: Bhuana Ilmu Populer, 2007). 
pembentukan perundangan-undangan yang baru. ${ }^{21}$

\section{Demoralisasi Hukum}

Ada proses demoralisasi yang panjang dalam dunia hukum kita. Juga ada masalah sistem yang mendukung munculnya demoralisasi tersebut. Sistem peradilan kolonial yang kita gunakan secara tambal sulam tidak direvisi total pada tataran prinsipil untuk memenuhi kebutuhan masyarakat akan peradilan yang berkeadilan namun lebih merupakan alat kontrol yang represif. Sehingga barang siapa yang ingin selamat dari jerat hukum, dia akan melakukan upaya-upaya kolusi yang mendorong suburnya demoralisasi.

Dasar dari seluruh permasalahan ini adalah tidak adanya visi, konsep dan strategi dalam masalah penegakan hukum dan keadilan. Tidak ada pendekatan baru dalam membangun image hukum kita kecuali sekadar meneruskan apa yang ditinggalkan rezim masa lalu. Masalahmasalah hukum hanya menjadi isu politik diluar jangkauan kekuasaan hukum.

Dalam pandangan filsuf Yunani Aristoteles, A state exists for the sake of a good life, and not for the sake of life only. Bahwa negara berdiri untuk sebuah kesejahteraan kehidupan, bukan sekadar kehidupan itu sendiri. Untuk sebuah kehidupan yang demokratis, maka rule of law hanya akan terwujud jika rakyat berpartisipasi melakukan apa yang disebut David Bethaam sebagai kegiatan popular control over collective decision-making and equality of rights in the exercise of that control. Disinilah berlaku kontrol yang efektif untuk meminimalisir penyalahgunaan wewenang pada sistem hukum kita.

\section{E. Penutup}

Memahami hukum Indonesia harus dilihat dari akar falsafah pemikiran yang dominan dalam kenyataanya tentang pengertian apa yang dipahami sebagai hukum serta apa yang diyakini sebagai sumber kekuatan berlakunya hukum. Dari uraian pada bagian terdahulu, tidak diragukan lagi bahwa apa yang dipahami sebagai hukum dan sumber kekuatan berlakunya hukum sangat dipengaruhi oleh aliran positivisme dalam ilmu hukum yang memandang hukum itu terbatas pada apa yang tertuang dalam peraturan perundang-undangan atau yang dimungkinkan berlakunya berdasarkan ketentuan peraturan perundang-undangan, bahkan aliran ini akan terus mengokohkan dirinya dalam perkembangan sistem hukum Indonesia ke depan. Adapun nilai-nilai moral dan etika serta kepentingan rakyat dalam kenyataan-kenyataan sosial di masyarakat hanya sebagai pendorong untuk terbentuknya hukum yang baru melalui perubahan, koreksi serta pembentukan peraturan perundang-undangan yang baru.

Kenyataan ini menunjukkan bahwa hukum adat dengan bentuknya yang pada umumnya tidak tertulis, yang sifatnya religio magis, komun, kontan dan konkrit (visual), sebagai hukum asli Indonesia semakin tergeser digantikan oleh paham positivis. Menurut Penulis, berbagai masalah kekecewaan pada penegakan hukum serta kekecewaan pada aturan hukum sebagian besarnya diakibatkan oleh situasi bergesernya

21 Hamdan Zoelva, "Hukum dan Politik Dalam Sistem Hukum Indonesia", Official Blog Hamdan Zoelva, http:// hamdanzoelva.wordpress.com/ (diakses 18 Oktober 2013). 
pemahaman terhadap hukum tersebut serta proses pembentukan hukum dan putusanputusan hukum yang tidak demokratis.

\section{DAFTAR PUSTAKA}

\section{Buku}

Achmad, Ali, Menguak Tabir Hukum, Suatu Kajian Filosofis dan Sosiologis, Cet. II (Jakarta: Penerbit Gunung Agung, 2002).

Asshidiqie, Jimly, Pokok-Pokok Hukum Tata Negara Indonesia (Jakarta: Bhuana IImu Pupuler, 2007).

Bushar, Muhammad, Asas-Asas Hukum Adat, Suatu Pengantar, Cet. Ke-4 (Jakarta: Pradnya Paramita, 1983).

Komar, Mieke, at al., Mochtar Kusumaatmadja: Pendidik dan Negarawan, Kumpulan Karya Tulis Menghormati 70 Tahun Prof. DR. Mochtar Kusumaatmadja, SH, LLM. (Bandung: Alumni, 1999).

Rasyidi, Lili \& Ira Rasyidi, Pengantar Filsafat dan Teori Hukum, Cet. ke VIII (Bandung: Citra Adtya Bakti, 2001).
S. Lev, Daniel, Hukum Dan Politik di Indonesia, Kesinambungan dan Perubahan, Cet I (Jakarta: LP3S, 1990).

Salman, Otje, Teori Hukum, Mengingat Mengumpulkan dan Membuka Kembali (Bandung: Refika Aditama, 2004).

Soekanto, Soerjono dan Sri Mamudji, Penelitian Hukum Normatif: Suatu Tinjauan Singkat (Jakarta: Raja Grafindo Persada, 2001).

\section{Makalah / Artikel / Prosiding / Hasil Penelitian}

Bagir Manan, "Tugas Sosial Pemerintahan Daerah:, opini, Pikiran Rakyat, 28 November 2008

Kisno Hadi," Satu Dasawarsa Relasi Politik Lokal Dan Nasional Dalam Konteks Otonomi Daerah" POLITIKA vol 1 No 2 (2010).

\section{Internet}

Hamdan Zoelva, "Hukum dan Politik Dalam Sistem Hukum Indonesia, Official Blog Hamdan Zoelva, http://hamdanzoelva.wordpress.com/ 